\title{
Effect of Vermicompost in Combination with Microbial Consortium on Growth of Chrysanthemum, (Dendranthema grandiflora L.) cv. Marigold
}

\author{
Sharukh Khan $^{1}$, M. Venkatesha ${ }^{2^{*}}$, P. Venkateshamurthy ${ }^{1}$ and D. Raghupathi ${ }^{3}$ \\ ${ }^{1}$ Department of Horticulture, College of Agriculture, University of Agricultural Sciences \\ Bengaluru, India \\ ${ }^{2}$ CoA V.C. Farm, Mandy, India \\ ${ }^{3}$ Directorate of Extension unit, ZARS, V.C. Farm, Mandya, Karnataka, India
}

*Corresponding author

\section{A B S T R A C T}

\begin{tabular}{|l|}
\hline Ke y w o r d s \\
Arka, Microbial \\
Consortium, \\
Vermicompost, \\
Plant growth, \\
Recommended \\
Dose of Fertilizers \\
\hline Article Info \\
\hline $\begin{array}{l}\text { Accepted: } \\
\text { 24 August } 2020 \\
\text { Available Online: } \\
\text { 10 September } 2020\end{array}$ \\
\hline
\end{tabular}

\section{Introduction}

Flowers are nature's the best gift. They are used in our day to day life for rituals and decoration purposes and it is a fast emerging business. Among the various flower crops Chrysanthemum (Dendranthema grandiflora L.) is an important cut and loose flower crop having a pivotal place in both domestic and international market, which occupies a prime place in ornamental Horticulture.
The present study was conducted to find out the influence of Vermicompost in combination with Microbial consortium on growth of Chrysanthemum (Dendranthema grandiflora L.) cv. Marigold was carried out at the Precision Farming Development Centre, Department of Horticulture, Gandhi Krishi Vigyana Kendra, University of Agricultural Sciences, Bengaluru during kharif season of 2018-19 and this experiment is laid out with a design of Randomised Complete Block Design (RCBD) with 10 treatment and 3 replication combination and this combination contains organic, inorganic and bio-fertilizers with a spacing of $45 \mathrm{~cm} \times 45 \mathrm{~cm}$ between the rows and plants. The results of the experiment indicated that treatment 9 (Vermicompost +50 per cent RDF + AMC) recorded significantly higher height $(50.14 \mathrm{~cm})$ more number of branches $(16.28)$, wide plant spread $\left(4342.25 \mathrm{~cm}^{2}\right)$ when compared to other treatments.

In modern agriculture, the farmers have been applying more than or under dose of fertilizers compared to recommended. As a consequence, it not only deteriorates soil health but also affects on yield and quality of the flowers. In view of this, there is a need to opt organic way which not only eco-friendly and support to obtain sustainable yield. In line of this, a study was conducted growing of chrysanthemum flower crop by adopting organic methods, using vermicompost with microbial consortium. 
Bio-fertilizers are more appropriately called 'microbial inoculants' containing live or latent cells of efficient strains of microorganisms. In recent times, FYM, vermicompost and biofertilizers have emerged as a supplement to mineral fertilizers and hold a promise to improve the yield as well as quality of the crop. Common biofertilizers used in horticultural crops are Azotobacter, Azospirillum, Phosphorous solubilising bacteria and VAM fungi. Azospirillum is a symbiotic N-fixing bacterium. Azotobacter and Azospirillum both fix atmospheric nitrogen when inoculated to plants, which help to save the application of $\mathrm{N}$ - fertilizers to an extent of 20-25 per cent.

Similarly, Phosphorous Solubilising Bacteria (PSB) is chief microorganisms, which are capable of mobilizing nutritive elements like non-usable phosphorus to plant usable phosphorus by biological processes.

Microbial consortium is a single carrier based microbial product that contains $\mathrm{N}$ fixing, $\mathrm{P} \&$ $\mathrm{Zn}$ solubilising and plant growth promoting microbes. This product is produced by using the efficient rhizosphere competent $\mathrm{N}$ fixing, nutrient solubilising and growth promoting bacteria screened from different agro ecological flower growing regions of Karnataka.

Therefore, present research was conducted to ascertain the influence of organic manures, inorganic fertilizers with a combination of microbial consortium on Chrysanthemum crop.

\section{Materials and Methods}

The experiment was conducted in Department of Horticulture, GKVK, University of Agricultural Sciences, Bengaluru by using cv. Marigold (Midgel). Twenty eight days old seedlings were transplanted in the main field.
The treatment details:

$\mathrm{T}_{1}-100 \%$ RDF (control); $\mathrm{T}_{2}-100 \% \mathrm{FYM} ; \mathrm{T}_{3}$ - $100 \%$ Vermicompost; $\mathrm{T}_{4}-100 \% \mathrm{RDF}+$ FYM(POP); $\mathrm{T}_{5}$ - Vermicompost $+75 \%$ RDF; $\mathrm{T}_{6}-$ Vermicompost $+75 \% \mathrm{RDF}+\mathrm{AMC}$;

$\mathrm{T}_{7}$ - Vermicompost+75\% RDF+ MC; $\mathrm{T}_{8}-$ Vermicompost $\quad+50 \% \quad \mathrm{RDF} ; \quad \mathrm{T}_{9^{-}}$ Vermicompost+50\% RDF + AMC; $\mathrm{T}_{10}-$ Vermicompost $+50 \% \mathrm{RDF}+\mathrm{MC}$.

Well decomposed organic sources of nutrient like FYM@ 25 tons and Vermicompost@ 7.5 tons per hectare were applied at the time of treatment imposition and mixed with soil. The recommended dose of 100:150:100 kg NPK/ha was applied in the form of Urea, Single super phosphate and Muriate of potash, respectively. Out of $100 \mathrm{~kg}$ Nitrogen, 50 per cent Nitrogen and full dose of $\mathrm{P}_{2} \mathrm{O}_{5}$ and $\mathrm{K}_{2} \mathrm{O}$ were applied in a circular band about $10 \mathrm{~cm}$ around each plant and remaining 50 per cent Nitrogen was given 30 days after planting as a top dressing. Bio-fertilizer like MC and AMC are applied to base of the plant (@5g/plant) as drenching, mulching sheet was used to cover the beds.

The plant height was recorded by selecting the five plants randomly in each replication in all the treatments after the 15 days of transplanting of chrysanthemum seedlings and those plants are tagged with a yellow tag to identify easily for further observations. The plant height was measured from ground level to the tip of the plant with the help of meter scale, at an interval of 30, 60, 75, 90 and 120 days after transplanting. The average plant height was calculated by dividing the summation with five and the average was expressed in centimetres, Plant spread is also an important parameter of vegetative growth of the plant and it was measured with a help of meter scale at an interval of 30, 60, 75, 90 and 120 DAT. It was measured between outermost leaves in east west and north south 
direction and expressed in centimetre square and number of branches per plant arising from the main stem were counted and recorded at $30,60,75,90$ and 120 days after transplanting in each replication under each treatment and expressed in number of branches / plant.

\section{Results and Discussion}

The plant height, spread and number of branches are significantly increased and differed due to application of organic manures, biofertilizers and inorganic fertilizers, at all the stages of crop growth. As the plant growth period increased, the plant height, spread and number of branches also significantly increased due to combined application of nutrient as compared to control.
Maximum plant height $(50.14 \mathrm{~cm})$ was recorded on application of Vermicompost + 50 per cent $\mathrm{RDF}+\mathrm{AMC}\left(\mathrm{T}_{9}\right)$ followed by $\mathrm{T}_{6}$ $(48.55 \mathrm{~cm})$ which received Vermicompost + 75 percent $\mathrm{RDF}+\mathrm{AMC}$ and minimum plant height was recorded in $T_{1}(38.46 \mathrm{~cm}) 100$ percent RDF at120 DAT (Table 1 and Graph$1)$.

There is an increasing trend noticed in plant spread (Table 1 and Graph-2). However, maximum plant spread from 30 DAT to 120 DAT was noticed in $\mathrm{T}_{9}$ (Vermicompost +50 per cent RDF + AMC) $4342.25 \mathrm{~cm}^{2}$ which was on par with $T_{6}\left(4100.65 \mathrm{~cm}^{2}\right)$ whereas, minimum plant spread was observed in $\mathrm{T}_{1}$ where 100 per cent RDF supplied (3215.21 $\mathrm{cm}^{2}$ ) (Fig. 1 and 2).

Table.1 Effect of Vermicompost and Microbial Consortium on vegetative parameters in Chrysanthemum cv. Marigold at 120 DAT

\begin{tabular}{|c|c|c|c|}
\hline Treatments & Plant height $(\mathrm{cm})$ & $\begin{array}{c}\text { Plant spread }\left(\mathrm{cm}^{2}\right) \\
\text { N-S X E-W }\end{array}$ & $\begin{array}{c}\text { Number of } \\
\text { branches/plant }\end{array}$ \\
\hline$T_{1}-100 \%$ RDF (Control) & 38.46 & 3215.21 & 12.34 \\
\hline $\mathrm{T}_{2}-100 \% \mathrm{FYM}$ & 41.42 & 3341.65 & 13.20 \\
\hline$T_{3}-100 \%$ Vermicompost & 42.17 & 3500.92 & 14.92 \\
\hline $\mathrm{T}_{4}-100 \% \mathrm{RDF}+\mathrm{FYM}(\mathrm{POP})$ & 42.99 & 3634.64 & 15.41 \\
\hline $\mathrm{T}_{5}-$ Vermicompost $+75 \% \mathrm{RDF}$ & 41.61 & 3875.49 & 15.73 \\
\hline $\mathrm{T}_{6}-$ Vermicompost $+75 \% \mathrm{RDF}+\mathrm{AMC}$ & 48.55 & 4100.65 & 16.10 \\
\hline $\mathrm{T}_{7}$ - Vermicompost+75\% RDF+ MC & 44.33 & 3650.25 & 14.57 \\
\hline $\mathrm{T}_{8}-$ Vermicompost $+50 \%$ RDF & 43.12 & 3731.51 & 13.81 \\
\hline $\mathrm{T}_{9}$ - Vermicompost+50\% RDF + AMC & 50.14 & 4342.25 & 16.28 \\
\hline $\mathrm{T}_{10}$-Vermicompost $+50 \%$ RDF $+\mathrm{MC}$ & 47.7 & 3957.67 & 15.94 \\
\hline F-test & $*$ & $*$ & $*$ \\
\hline S.Em \pm & 2.13 & 182.37 & 0.72 \\
\hline C.D.at 5\% & 6.31 & 541.85 & 2.13 \\
\hline
\end{tabular}

*Significant at 5\% confidence level, NS- non significant AMC - Arka Microbial Consortium (IIHR); DAT- Days After Transplanting; FYM-Farm Yard Manure (25 t/ha.) MC - Microbial Consortium (UASB); POP-Package of Practice ; RDF - Recommended Dose of Fertilizer (100:150:100 kg /ha N: P: K), VC- Vermicompost-7.5 t/ha. 
Fig.1
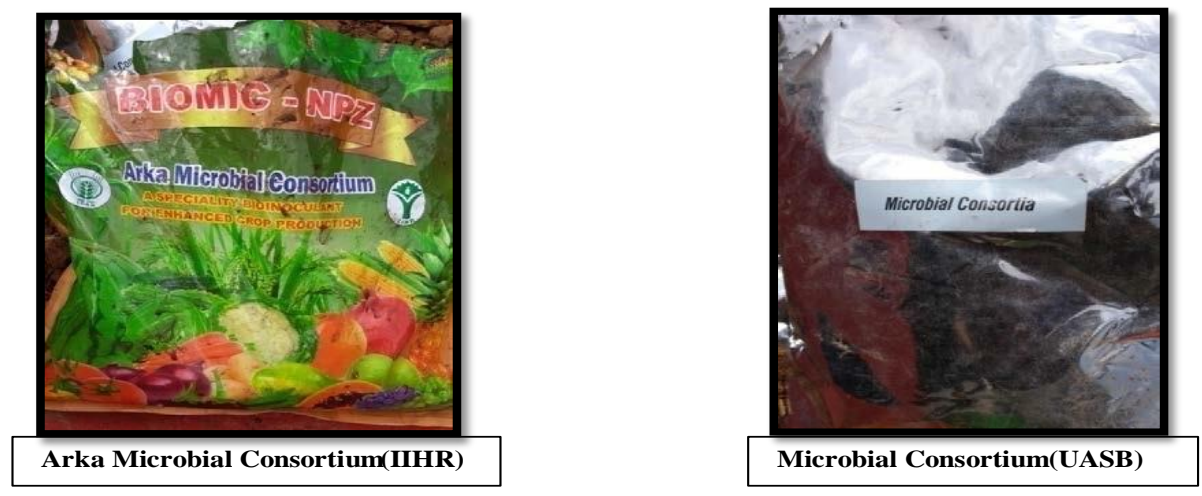

Fig.2

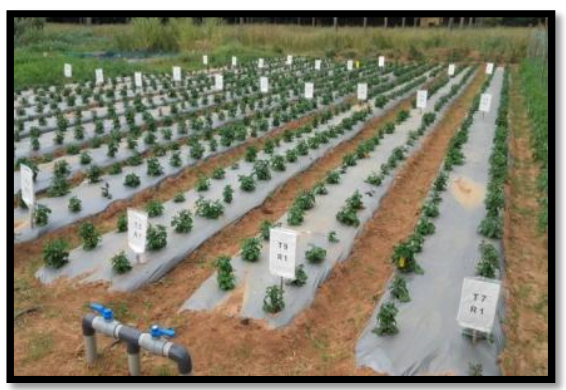

Experimental plot view at initial stage

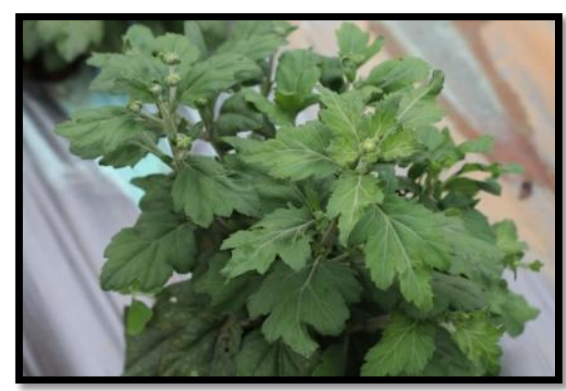

Chrysanthemum at flower initiation stage

Graph.1 Effect of Vermicompost and Microbial Consortium on plant height $(\mathrm{cm})$ of Chrysanthemum cv. Marigold

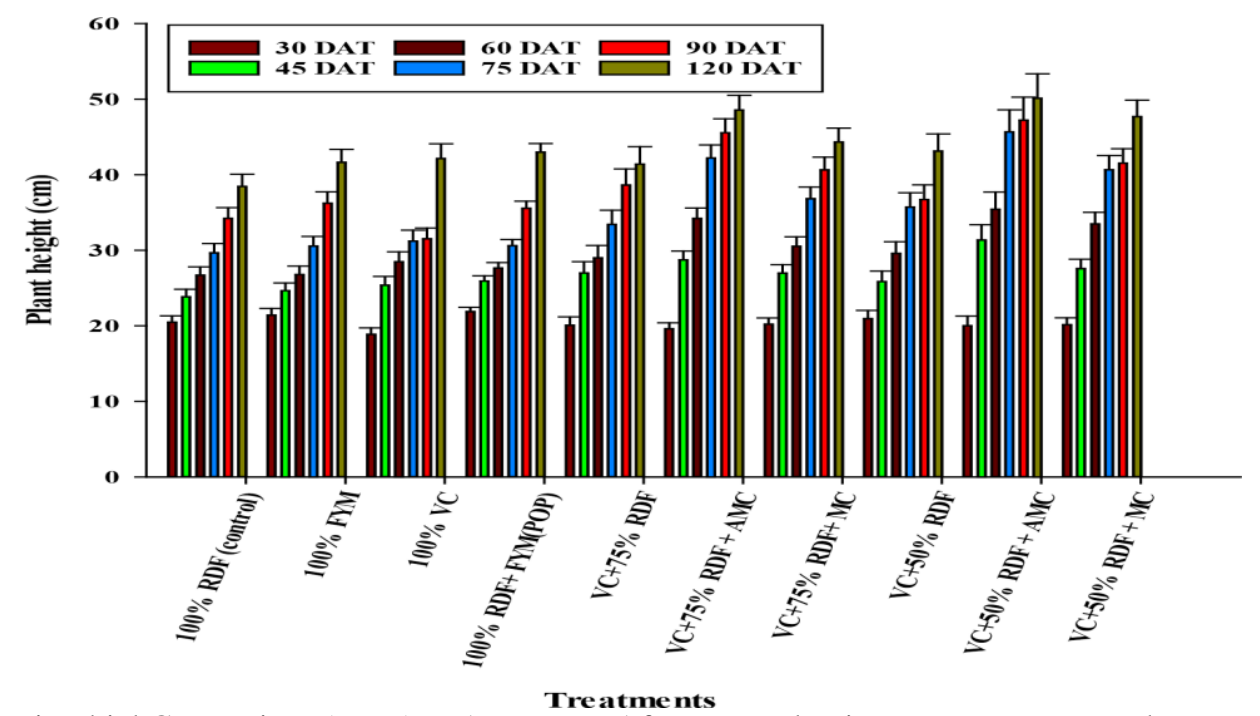

AMC - Arka Microbial Consortium (IIHR), DAT - Days After Transplanting, FYM- Farm Yard Manure (25 t/ha.), MC - Microbial Consortium (UASB), POP - Package of Practice, RDF - Recommended Dose of Fertilizer (100:150:100 kg /ha N: P: K), VC - Vermicompost-7.5 t/ha. 
Graph.2 Effect of Vermicompost and Microbial Consortium on plant spread $\left(\mathrm{cm}^{2}\right)$ of Chrysanthemum cv. Marigold

Treatments

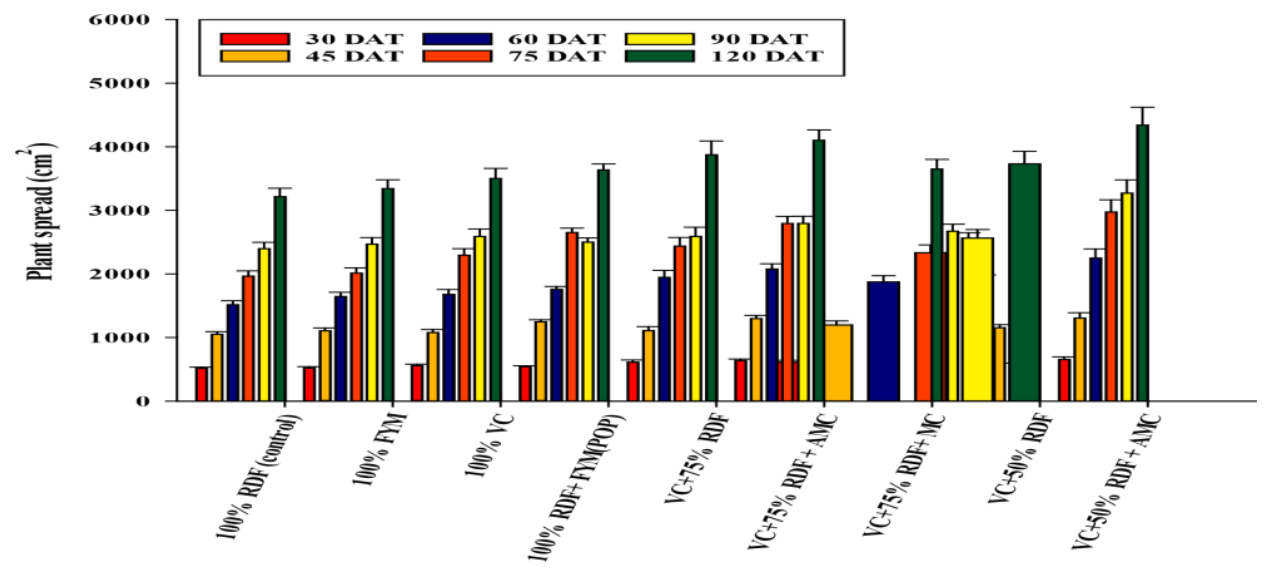

AMC - Arka Microbial Consortium (IIHR), ; AT- Days After Transplanting ; FYM- Farm Yard Manure (25 t/ha.) ; MC - Microbial Consortium (UASB); POP - Package of Practice; RDF - Recommended Dose of Fertilizer (100:150:100 kg /ha N: P: K); VC- Vermicompost-7.5 t/ha

Graph.3 Effect of Vermicompost and Microbial Consortium on number of branches of Chrysanthemum cv. Marigold

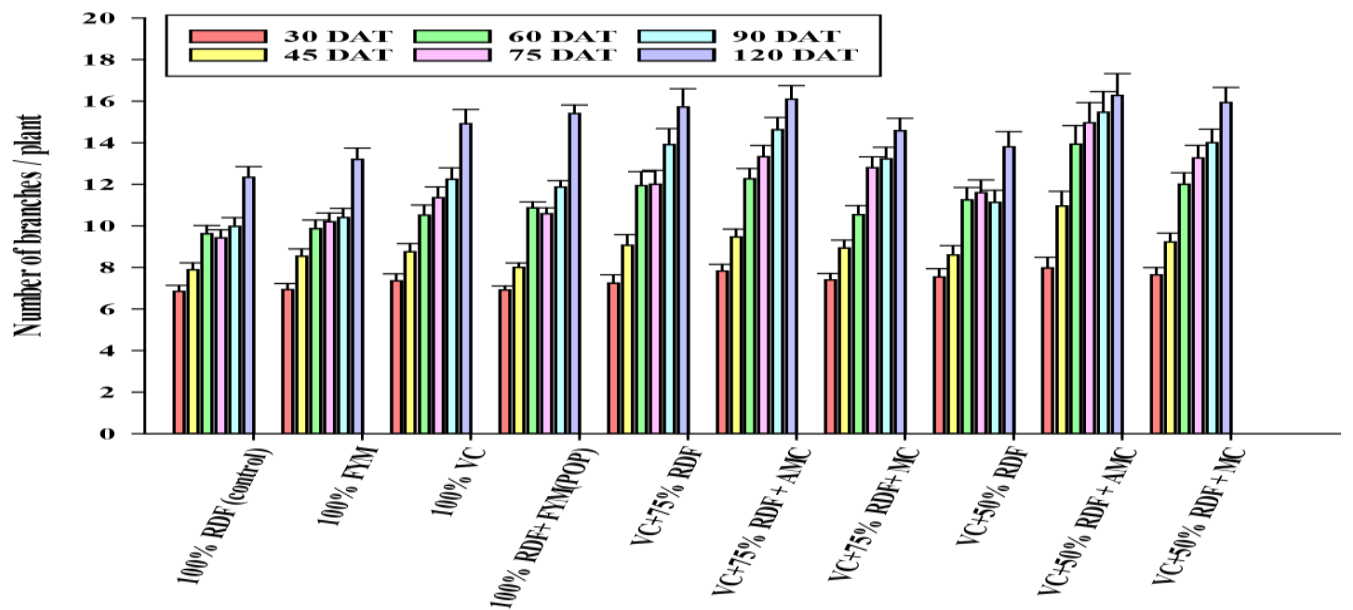

AMC - Arka Microbial Consortium (IIHR), DAT - Days After Transplanting ,FYM- Farm Yard Manure (25 t/ha.),

MC - Microbial Consortium (UASB), POP - Package of Practice, RDF - Recommended Dose of Fertilizer (100:150:100 kg /ha N: P: K), VC- Vermicompost-7.5 t/ha.

Maximum numbers of branches (Table and Graph-3) per plant are recorded in $\mathrm{T}_{9}$ Vermicompost +50 per cent $\mathrm{RDF}+\mathrm{AMC}$ (16.28) compared to minimum numbers in $\mathrm{T}_{1}$ where 100 per cent RDF applied (12.34). Application of 50 per cent RDF (N:P:K) in chrysanthemum crop, where nitrogen helps to increase the vegetative growth of the plant, phosphorus and potash helps to improves the quality parameter of the plants. Sunita et al., (2007) also noticed significantly higher plant height with application of vermicompost 50 per cent and RDF in African marigold.

Arka Microbial Consortium (AMC) which contains $\mathrm{N}$-fixing bacteria, phosphorus 
solubilising bacteria and zinc solubilizers helps the plant to get more of nutrient from the soil releases the fixed nutrients in the soil aggregates, these results are in conformity with the findings of Airadevi (2010) and Geeta pandey (2010) observed in chrysanthemum. Where application of Azospirillum + PSB +50 per cent vermicompost equivalent to $\mathrm{RDN}+50$ per cent recommended NPK recorded significantly maximum plant height and spread.

When two or three organisms are inoculated together, they are known to show better performance over single inoculations, possibly due to their synergistic interaction as noticed by Belimov et al., (1995) in barley, Alagawadi and Gaur, (1988) in chick pea.

The increase in number of branches may be attributed to vermicompost application which might have supplied plant nutrients directly to the plant resulting in stimulation of auxiliary buds thereby increasing number of branches per plant and also application of vermicompost which is considered as an excellent product as it is homogenous and has desirable properties, reduced level of contaminates, higher level of soil enzymes, plant growth hormones, greater microbial population and holds more nutrients over a longer period without adversely affecting the environment. The above results are in corroborate with the findings of Nethra et al., (1999) in China aster and Kusuma (2001) in Golden Rod.

In conclusion the results obtained in the present investigation reveals that application of nutrients from different sources significantly enhanced the vegetative parameters in Chrysanthemum cv. Marigold. It can be concluded that, application of vermicompost in combination with 50 per cent NPK and microbial consortium amalgamation/integration helps to maintain the soil fertility status to get sustainable crop yield and it is eco-friendly. On the contrary, the use of inorganic fertilizers which are costly and causing long term effects on flora, fauna and eco system, should be discouraged slowly.

\section{References}

Airadevi, P.A., 2010, Integrated nutrient management studies on growth, yield and quality of garland chrysanthemum (Chrysanthemum coronarium L.). M. Sc. (Agri.) Thesis, Uni. Agril. Sci., Dharwad.

Alagawadi, A. R. and Gaur, A. C., 1998, Associative effect of Rhizobium and phosphate solubilising bacteria on the yield and nutrient uptake of chickpea. Plant Soil., 105(2): 241-246

Belimov, A. A., Kojemiakov, P. A. and Chuvarliyeva, C. V., 1995, Interaction between barley and mixed cultures of nitrogen fixing and phosphate solubilising bacteria. Plant Soil., 17: 2937.

Geeta Pandey, Santosh Kumar. and Ajit Kumar., 2010, Effect of Integrated nutrient management on growth and flowering of Chrysanthemum (Dendranthema grandiflorum Tzvelev). J. Ornam. Hortic.,13(2): 112-116.

Kusuma, G., 2001, Effect of organic and inorganic fertilizers on growth yield and quality of Golden rod (Solidago candensis L) M.Sc. (Hort) Thesis College of Agriculture, Univ. Agric. Sci, Dharwad, Karnataka.

Nethra, N. N., Jayaprasad, K. V. and Radha, D. K., 1999, China aster (Callistephus chinensis L.) cultivation using vermicompost as organic amendment. Crop Res., 17(2): 209-215.

Sunita, H. M., Ravi Hunje, Vyakaranahal, B. S. and Bablad, H. B., 2007, Effect of 
plant spacing and integrated nutrient management on yield and quality of seed and vegetative growth parameters in
African marigold (Tagetes erecta Linn.). J. Ornam. Hortic., 10(4): 245-249.

\section{How to cite this article:}

Sharukh khan, M. Venkatesha, P. Venkateshamurthy and Raghupathi, D. 2020. Effect of Vermicompost in Combination with Microbial Consortium on Growth of Chrysanthemum, (Dendranthema grandiflora L.) cv. Marigold. Int.J.Curr.Microbiol.App.Sci. 9(09): 3436-3442. doi: https://doi.org/10.20546/ijcmas.2020.909.426 